\title{
Paracentrin 1, a synthetic antimicrobial peptide from the sea-urchin Paracentrotus lividus, interferes with staphylococcal and Pseudomonas aeruginosa biofilm formation
}

Domenico Schillaci ${ }^{1 *}$, Maria Grazia Cusimano ${ }^{1}$, Angelo Spinello ${ }^{1,2}$, Giampaolo Barone ${ }^{1,2}$, Debora Russo ${ }^{1,2}$, Maria Vitale ${ }^{3}$, Daniela Parrinello ${ }^{1}$ and Vincenzo Arizza ${ }^{1,2}$

\begin{abstract}
The rise of antibiotic-resistance as well as the reduction of investments by pharmaceutical companies in the development of new antibiotics have stimulated the investigation for alternative strategies to conventional antibiotics. Many antimicrobial peptides show a high specificity for prokaryotes and a low toxicity for eukaryotic cells and, due to their mode of action the development of resistance is considered unlikely. We recently characterized an antimicrobial peptide that was called Paracentrin 1 from the 5-kDa peptide fraction from the coelomocyte cytosol of the Paracentrotus lividus. In this study, the chemically synthesized Paracentrin 1, was tested for its antimicrobial and antibiofilm properties against reference strains of Gram positive and Gram negative. The Paracentrin 1 was active against planktonic form of staphylococcal strains (reference and isolates) and Pseudomonas aeruginosa ATCC 15442 at concentrations ranging from 12.5 to $6.2 \mathrm{mg} / \mathrm{ml}$. The Paracentrin 1 was able to inhibit biofilm formation of staphylococcal and Pseudomonas aeruginosa strains at concentrations ranging from 3.1 to $0.75 \mathrm{mg} / \mathrm{ml}$. We consider the tested peptide as a good starting molecule for novel synthetic derivatives with improved pharmaceutical potential.
\end{abstract}

Keywords: AMP (Antimicrobial peptides); Biofilm; Staphylococci; Pseudomonas aeruginosa; Paracentrotus lividus

\section{Introduction}

Many natural antimicrobial peptides show a high specificity for prokaryotes and a low toxicity for eukaryotic cells, and for their mode of action the development of resistance by pathogenic bacteria is considered unlikely (Hancock and Rozek 2002). At present, there has been an increase of interest in these molecules as potential new antimicrobials (Bax et al. 2000; Mor 2000).

In human medicine, chronic and persistent forms of some infectious diseases depend on the ability of pathogenic bacteria to develop bacterial communities called biofilms. Opportunistic pathogens, such as staphylococcal strains and Pseudomonas aeruginosa show a great ability to produce biofilms that preventing infected wounds to heal, render the treatment extremely challenging. In veterinary

\footnotetext{
* Correspondence: domenico.schillaci@unipa.it

'Dip. STEBICEF, Università degli Studi di Palermo, Via Archirafi, 32-90123 Palermo, Italy

Full list of author information is available at the end of the article
}

medicine, biofilms are believed to be involved in many diseases such as pneumonia, liver abscesses, enteritis, wound infections and mastitis, which is one of the most common diseases in dairy cattle (Clutterbuck et al. 2007). Staphylococcus aureus, a major pathogen of mastitis has good in vitro antimicrobial susceptibility, but the therapy used to treat the affected animals is often disappointing and results in chronic infections due to the growth of bacteria as biofilms (Melchior et al. 2006). The biofilm of $P$. aeruginosa is a severe complicating factor in bovine mastitis, which is often associated with contaminated udder washing water or contaminated intramammary dry-cow preparations (Melchior et al. 2009).

The treatment of biofilm-associated infections is complicated because microbial biofilms are typically highly resistant to conventional antibiotics (Gilbert et al. 2002). The discovery of anti-infective agents active not only against planktonic microorganisms but also against biofilms 
represents an important goal for an effective control of infections (Projan and Youngman 2002).

The antimicrobial defence system of marine invertebrates is an interesting source of new anti-infective agents (Arizza 2013). We focused, particularly, on the effector cells of the echinoderm immune system, the coelomocytes. In a recent study, the antimicrobial activity of a 5-kDa peptide fraction from coelomocyte cytosol (5-CC) of the Paracentrotus lividus, the sea-urchin from Mediterranean sea, was demonstrated in relation to a group of important human pathogens. The anti-biofilm activity of 5-CC was shown in S. epidermidis 1457, a clinical strain isolated from an infected central venous catheter, against reference staphylococcal biofilms and against Candida albicans and Candida tropicalis (Schillaci et al. 2010; Schillaci et al. 2012). We showed the presence of three principal peptides, in the 5-CC content, whose molecular weights were respectively 1251.7, 2088.1, and 2292.2. These peptides are the (9-19), (12-31), (24-41) fragments of a $\beta$-thymosin of $P$. lividus. We focused particularly on the smallest peptide, that we called paracentrin 1, 11 amino acids in length, because showed the common chemical-physical characteristics of an antimicrobial peptide (Wang and Wang 2004).

The present study was aimed at evaluating the antibacterial and anti-biofilm activity of a chemically synthesized paracentrin 1 (SP1) against a group of staphylococcal reference strains and isolates and against $P$. aeruginosa ATCC 15442.

\section{Materials and methods}

\section{Synthetic peptide}

The SP1 was purchased from CASLO, Lyngby, Denmark utilizing the following sequence EVASFDKSKLK derived from ESI-MS analysis. The peptide was synthesized using Fmoc solid phase technology and the peptide content and purity was determined by high performance liquid chromatography (HPLC) and mass spectrometry (MS) analysis.

Net molecular charge was calculated by using the following formula (1) and the pI was calculated by using a web tool (http://isoelectric.ovh.org/).

$$
z=\sum_{i} N_{i} \frac{10^{p K a_{i}}}{10^{p H}}-\sum_{j} N_{j} \frac{10^{p H}}{10^{p H}+10^{p K a_{j}}}
$$

Hydrophobic mean value was calculated by using the Liu-Deber hydrophobicity scale (Liu and Deber 1998). Secondary structure was evaluated utilizing the algorithm of Wang et al. (2009), present in antimicrobial peptide calculator web site (http://aps.unmc.edu/AP/prediction/ prediction_main.php). The helical wheel projection was performed using the Gautier et al. (2008) algorithm present in the HeliQuest site (http://heliquest.ipmc.cnrs.fr) with a window size of 11 residues.

\section{Microbial strains}

The staphylococcal reference strains used were: Staphylococcus aureus ATCC 29213, Staphylococcus aureus ATCC 25923, Staphylococcus aureus ATCC 6538, and Staphylococcus epidermidis RP62A, known for its ability to form a biofilm (Schumacher-Perdreau et al. 1994). Four staphylococcal isolates from the Istituto Zooprofilattico Sperimentale, Sicily (IZS) bacterial collection including strain 657 isolated from a milk sample from an individual sheep affected by mastitis, strain 688 and 700 and strain 702 isolated from bulk milk samples from different sheep flocks. The isolates were selected on blood agar plates and on Mannitol Salt Agar (Difco, Sparks, MD). The colonies were typed by API Staph strip (bio-Mérieux) and tube coagulase test was performed (Canicatti and Roch 1989).

Pseudomonas aeruginosa ATCC 15442, the reference strain in official tests for antibacterial evaluation in vitro (UNI EN European Standard), was also used in this study.

\section{Minimum inhibitory concentrations (MIC)}

MICs were determined by a micro-method described previously (Schillaci et al. 2005). Briefly, a series of solutions of SP1 was prepared with a range of concentrations from 25 to $0.07 \mathrm{mg} / \mathrm{ml}$ (obtained by two-fold serial dilution). The serial dilutions were made in Tryptic Soy Broth (TSB) (Merck) in a 96-wells plate; to each well was added $10 \mu \mathrm{l}$ of a bacterial suspension from a $24 \mathrm{~h}$ culture containing $\sim 1 \times 10^{6} \mathrm{CFU} / \mathrm{ml}$. The plate was incubated at $37^{\circ} \mathrm{C}$ for $24 \mathrm{~h}$; after this time, the MICs were determined by a microplate reader (ELX 800, Bio-Tek Instruments), and defined as the lowest concentration of compound whose O.D., read at $570 \mathrm{~nm}$, was comparable with the negative control wells (broth only, without inoculum).

\section{Evaluation of Biofilm formation}

All the bacterial reference strains were tested for their ability to form biofilms. Briefly, bacteria were grown in Tryptic Soy Broth (TSB, Sigma) containing $2 \%$ glucose overnight at $37^{\circ} \mathrm{C}$ in a shaking bath and then diluted 1:200 to a suspension with optical density (OD) of about 0.040 at $570 \mathrm{~nm}$ corresponding to $\sim 10^{6} \mathrm{CFU} / \mathrm{ml}$. Polystyrene 24-well tissue culture plates were filled with $1 \mathrm{ml}$ of diluted suspension and incubated for 24-hours at $37^{\circ} \mathrm{C}$. Then, the wells were washed three times with $1 \mathrm{ml}$ of sterile phosphate-buffered saline (PBS) and stained with $1 \mathrm{ml}$ of safranin $0.1 \% \mathrm{v} / \mathrm{v}$ for $1 \mathrm{~min}$. The excess stain was removed by placing the plates under running tap water. Plates were dried overnight in inverted position at $37^{\circ} \mathrm{C}$. Safranin stained adherent bacteria in each well were redissolved to homogeneity in $1 \mathrm{ml}$ of $30 \% \mathrm{v} / \mathrm{v}$ glacial acetic acid, and the OD was read at $492 \mathrm{~nm}$. Each assay was performed in triplicate and repeated at least twice. 


\section{Biofilm prevention assay}

Procedure described above was used to evaluate the activity of SP1 in preventing biofilm formation. Polystyrene 24-well tissue culture plates were filled with $1 \mathrm{ml}$ of diluted bacterial suspension (OD of about 0.040 at $570 \mathrm{~nm}$ ), obtained and diluted as previously seen, and sub-MIC concentrations, ranging from 6.2 to $0.7 \mathrm{mg} / \mathrm{ml}$, of SP1 were directly added to the bacterial suspension at time zero and incubated at $37^{\circ} \mathrm{C}$ for 24 hours. After that time the wells were washed and stained with safranin as seen in biofilm forming assay. By comparing the average optical density of the growth in control wells with that in the sample wells, the following formula was used to calculate the percentages of inhibition for each concentration of the sample:

$$
\text { Inhibition }(\%)=\frac{\mathrm{OD}_{570} \text { growth control- } \mathrm{OD}_{570} \text { sample }}{\mathrm{OD}_{570} \text { growth control }} \times 100
$$

Each assay was performed in triplicate and assays were repeated at least twice.

\section{Scanning electron microscopy}

The effects of SP1 on formation of bacterial biofilm were morphologically evaluated by scanning electron microscopy (SEM). Glass slides in the bottom of a polystyrene 24-well tissue culture plates, were filled with $1 \mathrm{ml}$ of a S. epidermidis RP62A suspension, obtained and diluted as previously seen, and a sub-MIC concentration of $3.1 \mathrm{mg} / \mathrm{ml}$ of SP1 was directly added at time zero and incubated at $37^{\circ} \mathrm{C}$ for 24 hours. After that time, the glass slides were gently washed four times with PBS to remove nonadherent bacteria and fixed with $2.5 \%$ glutaraldehyde- $2 \%$ paraformaldehyde in $0.1 \mathrm{M}$ cacodilate buffer ( $\mathrm{pH}$ 7.4) for $30 \mathrm{~min}$ at $4^{\circ} \mathrm{C}$. The bacterial preparation were washed with phosphate saline buffer PBS and post-fixed in osmium tetroxide $1 \%$ for $30 \mathrm{~min}$ at $4^{\circ} \mathrm{C}$, followed by an ethanol dehydration series: 15 minutes in 50:50 ethanol: $\mathrm{H}_{2} \mathrm{O}, 15$ minutes in $75: 25$ ethanol: $\mathrm{H}_{2} \mathrm{O}, 15$ minutes in 95:5 ethanol: $\mathrm{H}_{2} \mathrm{O}$, and 30 minutes in $100 \%$ ethanol than a critical point drying procedure was followed, and the preparations were mounted on aluminium stubs, and gold coated in a sputter coater. Imaging was conducted with a LEO 420 scanning electron microscope as previously reported (Arizza et al. 2011).

\section{Haemolytic assay}

The assay was performed as described (Arizza et al. 2013). In brief, freshly collected rabbit erythrocytes (RE) with heparin, kindly provided by the "Zooprophylaxis Institute of Sicily" (Palermo, Italy), were washed (400 g for $10 \mathrm{~min}$ at $4^{\circ} \mathrm{C}$ ) to remove the buffy coat, and the erythrocytes obtained were washed three times with phosphate-buffered saline (PBS: $6 \mathrm{mM} \mathrm{KH} \mathrm{KO}_{4} ; 30 \mathrm{mM} \mathrm{Na} 2 \mathrm{HPO}_{4} ; 0.11 \mathrm{M}$ $\mathrm{NaCl} ; \mathrm{pH} 7.4$ ) and suspended in $10 \mathrm{ml}$ PBS to obtain an $80 \times 10^{6}$ cells $/ \mathrm{ml}$ suspension. Aliquots of $200 \mu \mathrm{L}$ of $\mathrm{RE}$ suspension were mixed with $200 \mu \mathrm{l}$ of SP1 concentrations $(1.5,3.2,6.2$ and $50 \mathrm{mg} / \mathrm{ml})$ prepared in PBS, two-fold sequentially diluted $\mathrm{v} / \mathrm{v}$ with a PBS. After an $1 \mathrm{~h}$ incubation at $37^{\circ} \mathrm{C}$, the reaction mixture was centrifuged at $800 \mathrm{~g}$ for 15 min at $4^{\circ} \mathrm{C}$ to remove debris and residual erythrocytes. The O.D. of haemoglobin release was measured spectrophotometrically at a $541 \mathrm{~nm}$ wavelength. Spontaneous haemoglobin release $(0 \%)$ was estimated incubating the RE with PBS while the complete haemolysis (100\%) was assessed incubating the erythrocytes in a solution of $0.1 \%$ Triton-X 100 in distilled water and the haemolysis percentage was calculated according to the following equation:

$$
\text { Hemolysis }(\%)=\frac{-\mathrm{OD}_{541} \text { spontaneous } \mathrm{Hb} \text { release }}{\mathrm{OD}_{541} \text { complete } \mathrm{Hb} \text { release }} \times 100
$$

\section{Molecular dynamics simulations}

The molecular folding of the peptide in aqueous solution was investigated in silico by molecular dynamics (MD) simulations, following recently reported procedures (Lauria et al. 2014; Lentini et al. 2014). In details, a 400 ns of MD simulation was carried out at $300 \mathrm{~K}$, in the explicit water solvent and in the presence of $150 \mathrm{mM} \mathrm{Na}^{+}$and $\mathrm{Cl}^{-}$ counterions, using the Amber99SB-ILDN force field (Lindorff-Larsen et al. 2010) implemented in the GROMACS 4.6.5 software package (Pronk et al. 2013).

\section{Results}

\section{Molecular Dynamics of SP1}

SP1 is an 11-residue-long cationic peptide mainly enriched by residues such as lysine, with a $\mathrm{pI}$ of 10.72 and a net charge of +1 at $\mathrm{pH} 7.0$.

To investigate SP1 in physiological conditions, we performed a MD simulation using the model represented in Figure 1. The in silico study provided a comprehensive picture of the dynamic equilibrium existing among the possible backbone conformations of the small oligopeptide. In fact, the root mean square deviations (RMSD) in Figure 2 show that the peptide conformation continuously and consistently changes during the $400 \mathrm{~ns}$ of simulation. Essentially all possible backbone conformations are assumed. However, interestingly, between 150 and $250 \mathrm{~ns}$ the structure is more stable and preserved, before becoming again flexible and random. To analyse this time region quantitatively, we have reported the Ramachandran plot in Figure 3 of snapshots sampled every 10 ns. This plot shows that in this time range the different residues assume 


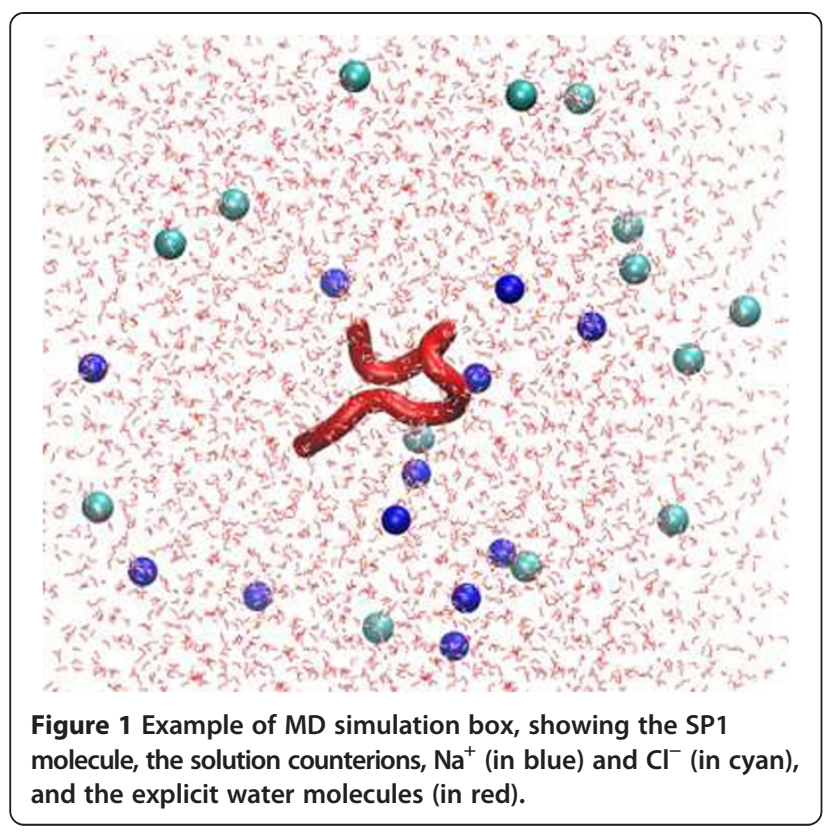

preferential local conformations. In particular, residues 2 , 3,4 and 8 are in the beta sheet conformation, residues 5, 6 and 9 are in the left-handed helix conformation, residue 7 is in the alpha helix conformation, while residue 10 is in the beta sheet conformation and only sporadically in the alpha helix conformation. The corresponding structure is depicted in Figure 4. The results obtained allow us to confirm that polar and apolar residues are not segregated on opposing surfaces through the long axis of the oligopeptide. In this peculiar conformation, the one that most frequently occurs in the investigated simulation time, the peptide possesses a hydrophobic non-amphipathic core constituted by $\mathrm{V}^{2}, \mathrm{~A}^{3}, \mathrm{~S}^{4}, \mathrm{~F}^{5}$ with a hydrophobic region placed between $\mathrm{E}^{1}$ and $\mathrm{D}^{6}$. These features confer to SP1 properties similar to the AMPs with hydrophobic core.

\section{Antibacterial activity of SP1}

SP1 was tested at concentrations ranging from 25 to $0.07 \mathrm{mg} / \mathrm{ml}$ against a group of Gram positive and Gram negative reference strains. The antibacterial activity of SP1, expressed as minimum inhibitory concentrations (MICs) against planktonic cells of staphylococcal reference strains and isolates from veterinary origin and $P$. aeruginosa is listed in Table 1. All bacterial strains showed susceptibility to the antibacterial action of SP1. In particular the strain of S. epidermidis RP62A resulted to be the most susceptible, indeed, the MIC value was $6.2 \mathrm{mg} / \mathrm{ml}$, while others attested to a value of $12.5 \mathrm{mg} / \mathrm{ml}$. SP1 was active against all isolates of animal origin strains and in particular showed the highest activity against the strain \#657 with a value of $6.2 \mathrm{mg} / \mathrm{ml}$ (Table 1).

\section{Interference with biofilm formation}

The interference with biofilm formation of SP1 against staphylococcal reference strains as S. aureus 25923, S. aureus 29213, S. aureus 6538, S. epidermidis RP62A and $P$. aeruginosa 15442 was observed. The inhibition was very evident to the highest concentrations of SP1 at $6.2 \mathrm{mg} / \mathrm{ml}$, when the values, for all strains, reached approximately $80 \%$. At the lowest concentrations of SP1 the degree of inhibition is reduced by following a dose dependence. $P$. aeruginosa strain 15442 was the most sensitive inhibitory activity of SP1, in fact, at a concentration of $3.1 \mathrm{mg} / \mathrm{ml}$, a value of about $73 \%$ inhibition was observed, while for the other strains the inhibition values were of around 50\% (Figure 5).

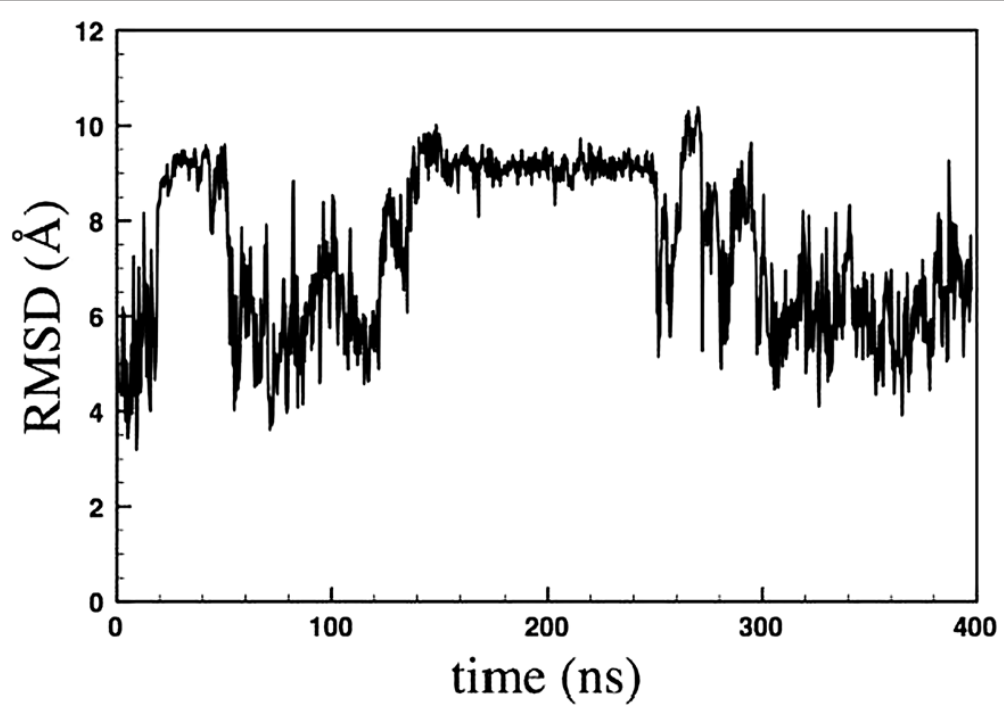

Figure 2 Plot of the RMSD obtained for SP1 up to 400 ns of MD simulation. 


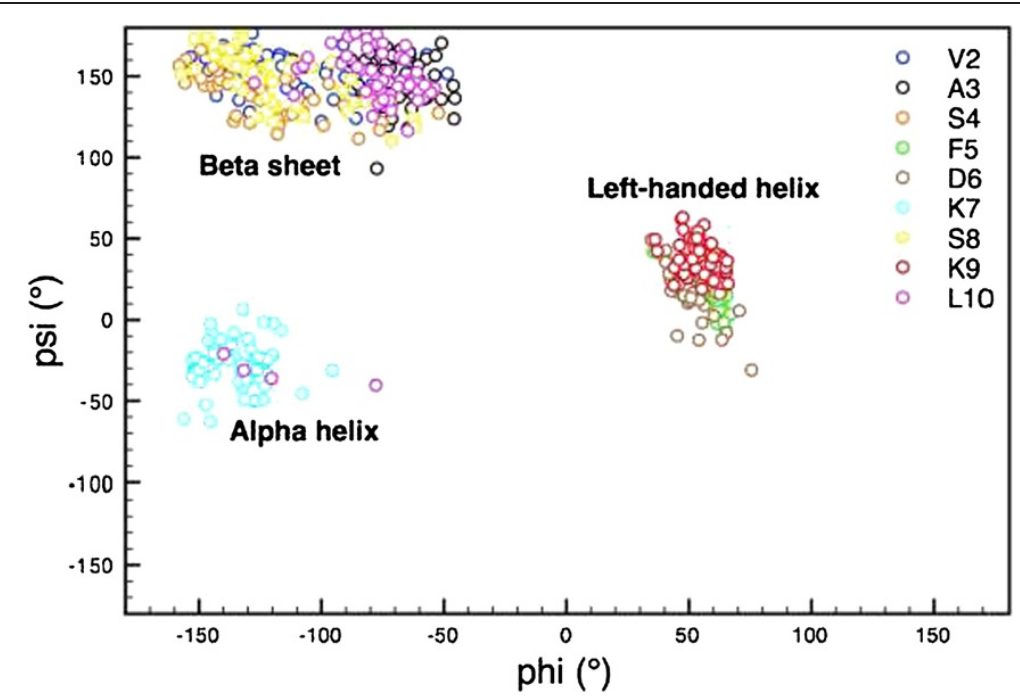

Figure 3 Ramachandran plot showing the values of psi and phi angles assumed by residues 2-10 of SP1 between 150 and 250 ns of the MD simulation.

SEM analysis was carried out to visualize the detailed architecture of biofilm and the antibiofilm effects of SP1 on bacterial biofilm of $S$. epidermidis RP62A (Figure 6). The control biofilm after $24 \mathrm{~h}$ was composed by multilayered conglomerated bacterial cells clusters that produced a dense biofilm matrix (Figure 6A). Sub MIC concentration $(3.1 \mathrm{mg} / \mathrm{ml})$ of SP1 was able to inhibit the formation of a multistratified structure, in fact in the sample treated with SP1 we found few monostratified bacterial cell clusters respect to the growth control (Figure 6B).

\section{Haemolytic assay}

The haemolytic activity of antimicrobial peptides against mammalian erythrocytes is often used as a preliminary evaluation of their selective toxicity and of the interactions of the cationic peptides with negatively charged membranes (Fischer et al. 2003; Wu et al. 2010) The performed hemolytic experiment to evaluate the interaction and the potential toxicity of the peptides SP1 did not show a measurable toxic effect against RBC ( 1\%) at MIC concentrations. A slight haemolytic activity, about $11.8 \%$,

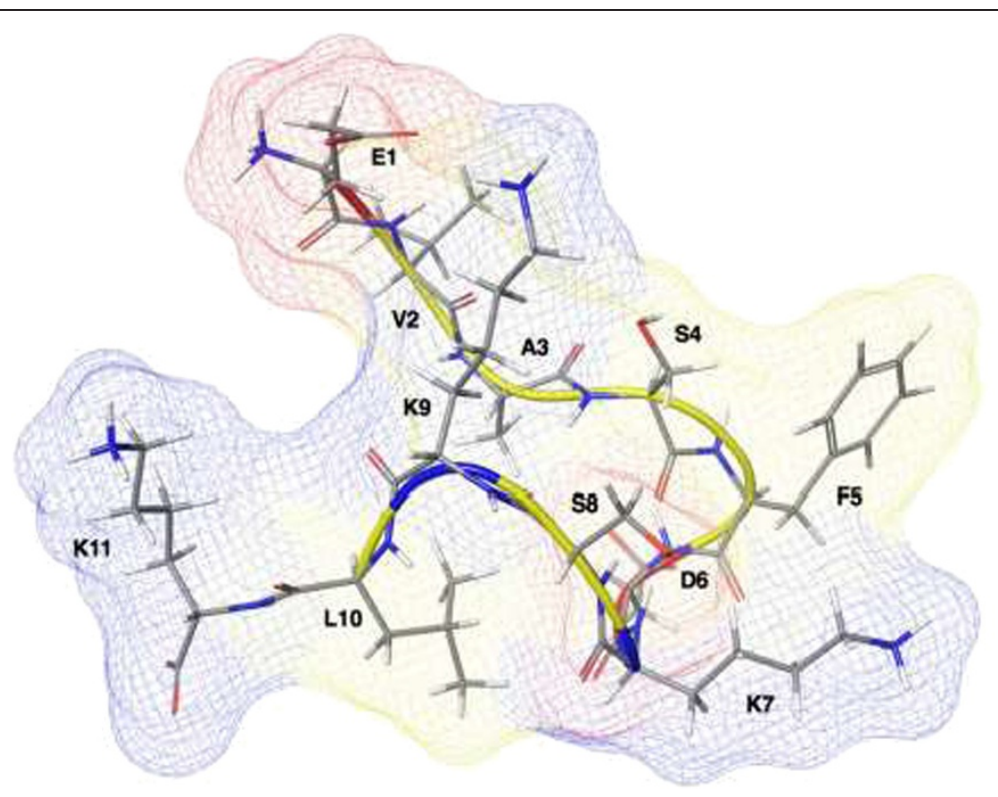

Figure 4 Molecular representation of SP1 at about $200 \mathrm{~ns}$ of MD showing the non amphipathic structure of the peptide. The potential surface is superimposed. Color code: acidic residues in red, basic residues in blue, and hydrophobic residues in yellow. 
Table 1 MIC values of SP1 tested against bacterial strains

\begin{tabular}{ll}
\hline Bacterial strains & MIC $(\mathbf{m g} / \mathbf{m l})$ \\
\hline S. aureus ATCC 25923 & 12.5 \\
S. aureus ATCC 29213 & 12.5 \\
S. aureus ATCC 6538 & 12.5 \\
S. epidermidis RP62A & 6.2 \\
S. aureus 100 & 12.5 \\
S. aureus 657 & 6.2 \\
S. aureus 700 & 12.5 \\
S. aureus 702 & 12.5 \\
P. aeruginosa ATCC15442 & 12.5 \\
\hline
\end{tabular}

MIC values for each strain are the means of three different assays performed in duplicate

was evident only at the highest concentration $(50 \mathrm{mg} / \mathrm{ml})$ (Figure 7).

\section{Discussion}

The echinoderms are considered a good source for AMPs and a variety of peptides with antimicrobial properties have been isolated from them. Antimicrobial activity has been reported in gonads of the asteroid Marthasterias glacialis (Stabili and Pagliara 1994), and Paracentrotus lividus contains, in the low molecular weight fraction $(<5 \mathrm{kDa})$ of acid precipitate of their coelomocytes, peptides with antimicrobial activity against staphylococcal biofilms. In addition, we recently reported that immune mediators cells in the echinoderm Holothuria tubulosa is a source of novel AMPs with anti-staphylococcal biofim activity (Schillaci et al. 2013). Moreover, two cystein-rich AMPs, named centrocyns, have been characterized in the green sea-urchin Strongylocentrotus droebachiensis (Li et al. 2010).
The synthetic fragment SP1 of $\beta$-thymosin extracted from coelomocytes of the P. lividus shares structural characteristics of many antimicrobial peptides: it is a cationic peptide and possesses a significant proportion ( 40\%) of hydrophobic or non polar residues (Hancock and Lehrer 1998; Zasloff 2002). Although the $\alpha$-helix is the most common secondary structure for the antimicrobial activity of AMPs (Mor and Nicolas 1994; Skerlavaj et al. 1996; Storici et al. 1994; Tossi et al. 1994) the in silico study suggests that the conformation assumed by SP1 (Figure 4) might be responsible for the observed antimicrobial activity. The helix structure of echinoderm AMPs shares a characteristic amphipathic structure with alternating hydrophobic and polar residues along the primary structure. According to the Shai-Matsuzaki-Huang model, the peptides bind to the membrane surface first and then with their amphipathic structure they enter into the membrane, breaking up the lipid chains and forming transient pore; this process can cause a collapse of the membrane at a critical peptide concentration (Hancock and Chapple 1999; Huang 2000; Matsuzaki 1998; Shai 2002). The SP1 peptide has a structure very different from other echinoderm AMPs (Schillaci et al. 2013; Schillaci et al. 2012). Moreover, such structure, unexpectedly, does not have an amphipathic nature with a hydrophobic face opposite to a hydrophilic one, because the polar charged residues and those hydrophobic are not arranged uniformly. The peptide contains a sequence of four hydrophobic/non polar residues which contribute to constitute a hydrophobic core, flanked at both ends by cationic and polar residues that can solubilize the peptides in aqueous solution providing a binding site for bacterial membranes. This particular conformation is different from other antimicrobial peptides, designed as transmembrane mimetic models and that spontaneously become inserted into the cell

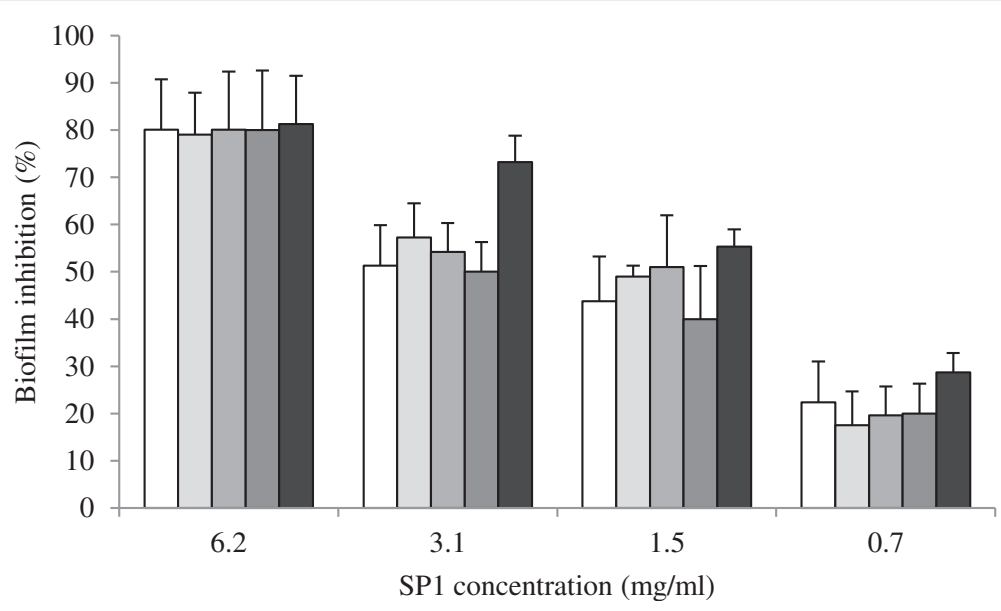

Figure 5 Interference with biofilm formation of SP1 against reference staphylococcal and $P$. aeruginosa strains. The percentage of inhibition were evaluated comparing the samples with not-treated $24 \mathrm{~h}$ old biofilms and staining with safranin. Bacterial strains $\square$ S. aureus 25923, $\square$ S. aureus 29213, $\square$ S. aureus 6538, $\square$ S. epidermidis RP62A, $\square$ P. aeruginosa 15442. Data for each strain are the mean of three distinct experiments \pm S.D. 

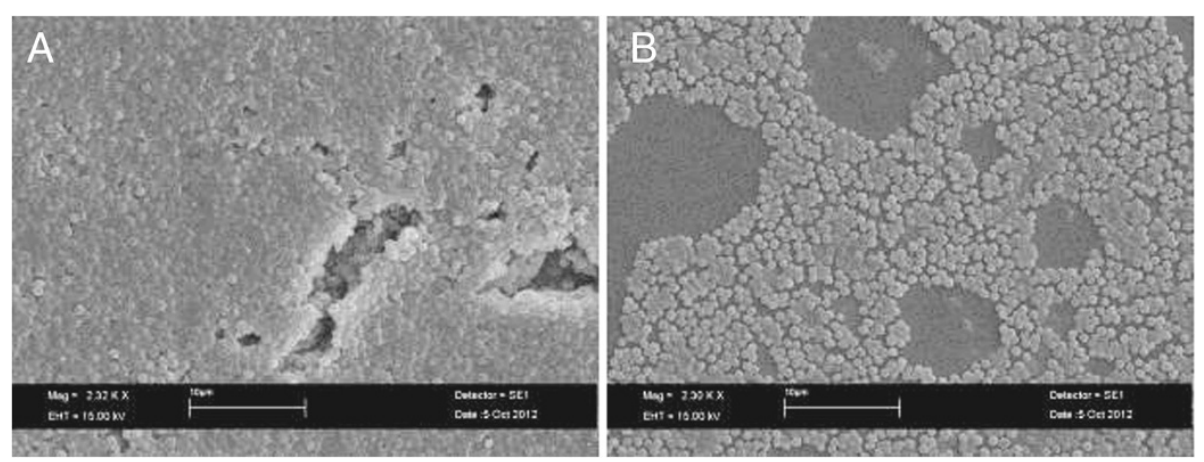

Figure 6 SEM micrography showing the effect of sub-MIC concentration of SP1 on S. epidermidis RP62A biofilm formation. A) Growth control (not treated with SP1); B) sample treated with a sub-MIC concentration $(3.1 \mathrm{mg} / \mathrm{ml})$ of SP1.

membranes (Chan et al. 2004; Liu and Deber 1998; Stark et al. 2002).

We found that the SP1 showed a broad antimicrobial activity against important pathogens such as $S$. aureus and $P$. aeruginosa but it acts at high concentration (12.5 or $6.2 \mathrm{mg} / \mathrm{ml}$ ) against planktonic forms of these two microorganisms. Such weak activity is comparable to that reported for a different Echinoderm, Holothuria tubulosa (Schillaci et al. 2013) and to that of some described innate human defence protein like lactoferrin in vitro (de Andrade et al. 2014). MD results suggest that the observed weak activity could be due to the low stability of SP1, in fact, as showed in RMSD plot (Figure 2), the molecule is stable only in a limited time period and in this period it can present the active conformation of Figure 1. However, SP1 shows an interesting additional antimicrobial effect interfering with biofilm formation in vitro of the above cited pathogens, at lower concentrations than MIC evaluated against the planktonic forms. The prevention of biofilm formation rather than its elimination - is the best strategy to contrast the growth, as a sessile community, of many pathogens.
We do not know the antimicrobial mechanisms of SP1, but we could speculate as for other cationic nonamphipathic microbial peptides that the positive charges carried by the peptide are essential for the membrane binding through electrostatic interaction between residues with anionic phospholipids. The peptide-membrane interaction could be responsible for membrane aggregation by peptides bridging simultaneously two membranes or for negative curvature of the membrane asymmetry that can form tubes (Lamaziere et al. 2007). The synthetic SP1 could act like Dermaseptin S9, a non-amphipathic antimicrobial peptides produced by the skin of the South American hylid frog, Phyllomedusa sauvagei, that contains, centrally located, a hydrophobic core that can insert the peptide in interior membrane (Lequin et al. 2006). Dermaseptin S9 exerts a microbicidal activity by perturbating both the membrane interface and the hydrophobic core of the bacterial membrane (Auvynet et al. 2008).

In a preliminary evaluation of selective toxicity, it was gratifying to note the general lack of hemolysis of rabbit erythrocytes by SP1, even at peptide concentrations up to

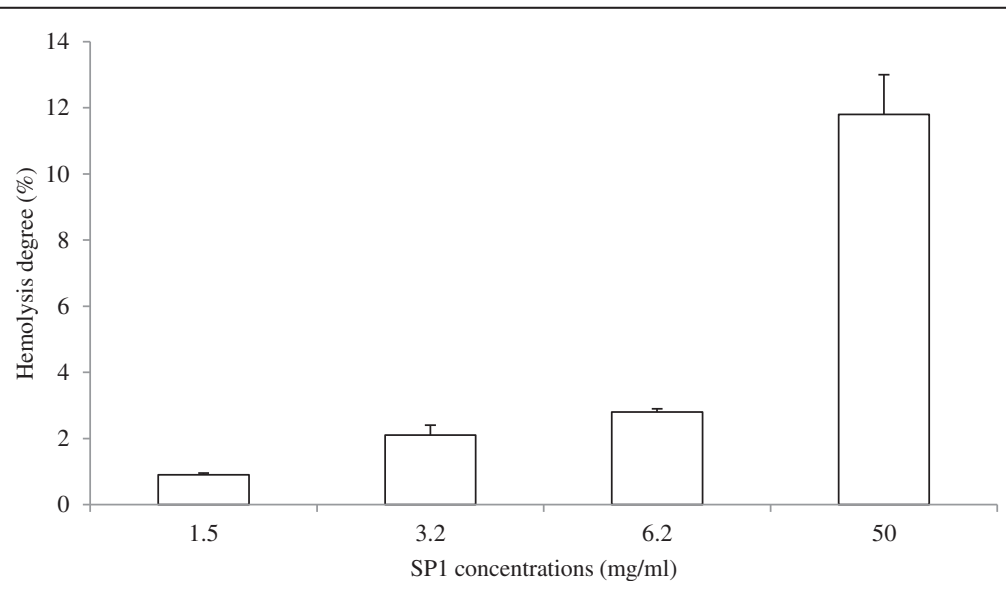

Figure 7 Hemolytic activity of SP1 peptides from Paracentrotus lividus hemocytes against rabbit blood cells at different concentrations: $1.5 \mathrm{mg} / \mathrm{ml} ; 3.2 \mathrm{mg} / \mathrm{ml} ; 6.2 \mathrm{mg} / \mathrm{ml} ; 50 \mathrm{mg} / \mathrm{ml}$. Data are the mean value of three separate experiments and expressed as percentage of hemolysis \pm SD 
$50 \mathrm{mg} / \mathrm{ml}$. Such selectivity of cationic non amphipathic antimicrobial peptides for bacterial membranes may be explicable, in part, by the differences in the compositions of eukaryotic and prokaryotic membranes (Matsuzaki 1999; Zasloff 2002). The outer leaflet of mammalian cells is predominantly composed of the zwitterionic phospholipids phosphatidylcholine and sphingomyelin (Verkleij et al. 1973), along with cholesterol (Turner and Rouser 1970), while bacterial membranes contain mainly anionic phospholipids and no cholesterol (Brock 1974). In addition, the outer surfaces of Gram-negative bacteria contain lipopolysaccharides, while those of Gram-positive bacteria contain teichoic acid, which in both cases add to the negative charge of the bacterial surface (Brock 1974). The cationic nature of native antimicrobial peptides clearly contributes to their preferential recognition by the negatively charged outer surfaces of bacterial membranes (Oren and Shai 1998; Shai 1999).

The extensive clinical use of classical antibiotics has led to the growing emergence of many medically relevant resistant strains of pathogens (Patel 2005). Therefore, the development of a new class of antimicrobials with a different mechanism of action than conventional antibiotics has become critical. The cationic antimicrobial peptides could represent such a new class (Andreu and Rivas 1998; Hancock 1997; Sitaram and Nagaraj 2002). The development of resistance to membrane active peptides whose sole target is the cytoplasmic membrane is not expected because this would require substantial changes in the lipid composition of cell membranes of microorganisms (Hancock 2001).

The anti-adhesion property showed by SP1 against $S$. aureus and $P$. aeruginosa strains is very interesting considering that the two opportunistic pathogens are able to form biofilms in open wounds, such as chronic diabetic foot ulcers, or infected wounds in clinical and veterinary medicine. New antimicrobial agents that are effective against staphylococci and $P$. aeruginosa to treat infected wounds are needed, and a potential topical application of SP1 could be supposed. Moreover, the two species are also involved in food spoilage and biofilm formation of food transmitted pathogens and an application of SP1 in the food processing is possible and closer, at this stage of our study, than application in clinical or veterinary health.

A chemotherapeutic approach combining conventional antibiotics and novel anti-biofilm agents could be a new strategy for the treatment of biofilm-associated infections like mastitis in veterinary field or the topical treatment of infected wounds in clinical and veterinary setting.

Finally, the tested synthetic peptide is a good starting point to design new synthetic derivatives with modified chemicalphysical properties, with the aim to improve their antimicrobial activity against pathogens and their pharmaceutical potential (Brogden and Brogden 2011; Huang et al. 2010).

\section{Competing interests}

The authors declare that they have no competing interests.

\section{Acknowledgements}

Financial support from Fondi di Ateneo 2006, 2007 Università degli Studi di Palermo (Italy) and Ministero della Salute IZS is gratefully acknowledged.

\section{Author details}

${ }^{1}$ Dip. STEBICEF, Università degli Studi di Palermo, Via Archirafi, 32-90123 Palermo, Italy. ${ }^{2}$ IEMEST, Istituto Euromediterraneo di Scienza e Tecnologia, Via Emerico Amari, 123-90139 Palermo, Italy. ${ }^{3}$ Istituto Zooprofilattico

Sperimentale della Sicilia "A. Mirri", Via G. Marinuzzi, 3-90129 Palermo, Italy.

Received: 13 June 2014 Accepted: 5 October 2014

Published online: 31 October 2014

\section{References}

Andreu D, Rivas L (1998) Animal antimicrobial peptides: an overview. Biopolymers 47(6):415-433

Arizza V (2013) Marine biodiversity as source of new drugs. Ital J Zool 80(3):317-318, doi:10.1080/11250003.2013.830370

Arizza V, Parrinello D, Cammarata M, Vazzana M, Vizzini A, Giaramita FT, Parrinello N (2011) A lytic mechanism based on soluble phospholypases A2 (sPLA2) and beta-galactoside specific lectins is exerted by Ciona intestinalis (ascidian) unilocular refractile hemocytes against K562 cell line and mammalian erythrocytes. Fish Shellfish Immun 30(4-5):1014-1023, doi:10.1016/j.fsi.2011.01.022

Arizza V, Vazzana M, Schillaci D, Russo D, Giaramita FT, Parrinello N (2013) Gender differences in the immune system activities of sea urchin Paracentrotus lividus. Comp Biochem Physiol A Mol Integr Physiol 164(3):447-455, doi:10.1016/j. cbpa.2012.11.021

Auvynet C, El Amri C, Lacombe C, Bruston F, Bourdais J, Nicolas P, Rosenstein Y (2008) Structural requirements for antimicrobial versus chemoattractant activities for dermaseptin S9. FEBS J 275(16):4134-4151, doi:10.1111/j.17424658.2008.06554.x

Bax R, Mullan N, Verhoef J (2000) The millennium bugs - the need for and development of new antibacterials. Int J Antimicrob Ag 16(1):51-59, doi:10.1016/S0924-8579 (00)00189-8

Brock TD (1974) Biology of Microorganisms, 2nd edn. Prentice-Hall, Inc, Englewood Cliffs N.J

Brogden NK, Brogden KA (2011) Will new generations of modified antimicrobial peptides improve their potential as pharmaceuticals? Int J Antimicrob Ag 38(3):217-225, doi:10.1016/j.jijantimicag.2011.05.004

Canicatti C, Roch P (1989) Studies on Holothuria polii (Echinodermata) Antibacterial Proteins.1. Evidence for and Activity of a Coelomocyte Lysozyme. Experientia 45(8):756-759, doi:10.1007/Bf01974579

Chan C, Burrows LL, Deber CM (2004) Helix induction in antimicrobial peptides by alginate in biofilms. J Biol Chem 279(37):38749-38754, doi:10.1074/jbc. M406044200

Clutterbuck AL, Woods E, Knottenbelt DC, Clegg PD, Cochrane CA, Percival SL (2007) Biofilms and their relevance to veterinary medicine. Vet Microbiol 121(1-2):1-17, doi:10.1016/j.vetmic.2006.12.029

de Andrade FB, de Oliveira JC, Yoshie MT, Guimarães BM, Gonçalves RB, Schwarcz WD (2014) Antimicrobial activity and synergism of lactoferrin and lysozyme against cariogenic microorganisms. Braz Dent J 25:165-169

Fischer D, Li Y, Ahlemeyer B, Krieglstein J, Kissel T (2003) In vitro cytotoxicity testing of polycations: influence of polymer structure on cell viability and hemolysis. Biomaterials 24(7):1121-1131, doi:10.1016/S0142-9612(02)00445-3

Gautier R, Douguet D, Antonny B, Drin G (2008) HELIQUEST: a web server to screen sequences with specific a-helical properties. Bioinformatics 24(18):2101-2102, doi:10.1093/bioinformatics/btn392

Gilbert P, Allison DG, McBain AJ (2002) Biofilms in vitro and in vivo: do singular mechanisms imply cross-resistance? J Appl Microbiol 92:98s-110s, doi:10.1046/ j.1365-2672.92.5s1.5.x

Hancock REW (1997) Peptide antibiotics. Lancet 349(9049):418-422, doi:10.1016/ S0140-6736(97)80051-7

Hancock RE (2001) Cationic peptides: effectors in innate immunity and novel antimicrobials. Lancet Infect Dis 1(3):156-164, doi:10.1016/S1473-3099(01)00092-5

Hancock RE, Chapple DS (1999) Peptide antibiotics. Antimicrob Agents Chemother 43(6):1317-1323

Hancock RE, Lehrer R (1998) Cationic peptides: a new source of antibiotics. Trends Biotechnol 16(2):82-88 
Hancock RE, Rozek A (2002) Role of membranes in the activities of antimicrobial cationic peptides. FEMS Microbiol Lett 206(2):143-149

Huang HW (2000) Action of antimicrobial peptides: Two-state model. Biochemistry 39(29):8347-8352, doi:10.1021/Bi0009461

Huang YB, Huang JF, Chen YX (2010) Alpha-helical cationic antimicrobial peptides: relationships of structure and function. Protein Cell 1(2):143-152, doi:10.1007/ s13238-010-0004-3

Lamaziere A, Burlina F, Wolf C, Chassaing G, Trugnan G, Ayala-Sanmartin J (2007) Non-metabolic membrane tubulation and permeability induced by bioactive peptides. Plos One 2(2):e201, doi:10.1371/journal.pone.0000201

Lauria A, Bonsignore R, Terenzi A, Spinello A, Giannici F, Longo A, Almerico AM, Barone G (2014) Nickel(II), copper(II) and zinc(II) metallo-intercalators: structural details of the DNA-binding by a combined experimental and computational investigation. Dalton Trans 43:6108-6119, http://dx.doi.org/10.1039/c3dt53066c

Lentini L, Melfi R, Di Leonardo A, Spinello A, Barone G, Pace A, Palumbo Piccionello A, Pibiri I (2014) Towards a rationale for the PTC124 (Ataluren) promoted readthrough of premature stop codons: a computational approach and GFPreporter cell-based assay. Mol Pharm 11:653-664, http://dx.doi.org/10.1021/ mp400230s

Lequin O, Ladram A, Chabbert L, Bruston F, Convert O, Vanhoye D, Chassaing G, Nicolas P, Amiche M (2006) Dermaseptin S9, an alpha-helical antimicrobial peptide with a hydrophobic core and cationic termini. Biochemistry 45(2):468-480, doi:10.1021/bi051711i

Li C, Haug T, Moe MK, Styrvold OB, Stensvåg K (2010) Centrocins: Isolation and characterization of novel dimeric antimicrobial peptides from the green sea urchin, Strongylocentrotus droebachiensis. Dev Comp Immunol 34:959-968, doi: 10.1016/j.dci.2010.04.004

Lindorff-Larsen K, Piana S, Palmo K, Maragakis P, Klepeis JL, Dror RO, Shaw DE (2010) Improved side-chain torsion potentials for the Amber ff99SB protein force field. Proteins 78:1950-1958, http://dx.doi.org/10.1002/prot.22711

Liu L-P, Deber CM (1998a) Guidelines for membrane protein engineering derived from de novo designed model peptides. Pept Sci 47(1):41-62, doi:10.1002/ (SICI)1097-0282(1998)47:1<41::AID-BIP6>3.0.CO;2-X

Liu LP, Deber CM (1998b) Guidelines for membrane protein engineering derived from de novo designed model peptides. Biopolymers 47(1):41-62, doi:10.1002/(SICI)1097-0282(1998)47:1<41“.AID-BIP6>3.0.CO:2-X

Matsuzaki K (1998) Magainins as paradigm for the mode of action of pore forming polypeptides. Biochim Biophys Acta Rev Biomembr 1376(3):391-400, doi:10.1016/S0304-4157(98)00014-8

Matsuzaki K (1999) Why and how are peptide-lipid interactions utilized for selfdefense? Magainins and tachyplesins as archetypes. Biochim Biophys Acta Rev Biomembr 1462(1-2):1-10, http://dx.doi.org/10.1016/S0005-2736(99) 00197-2

Melchior MB, Vaarkamp H, Fink-Gremmels J (2006) Biofilms: a role in recurrent mastitis infections? Vet J 171(3):398-407, doi:10.1016/j.tvjl.2005.01.006

Melchior MB, van Osch MHJ, Graat RM, van Duijkeren E, Mevius DJ, Nielen M, Gaastra W, Fink-Gremmels J (2009) Biofilm formation and genotyping of Staphylococcus aureus bovine mastitis isolates: Evidence for lack of penicillin-resistance in Agr-type II strains. Vet Microbiol 137(1-2):83-89, doi:10.1016/j.vetmic.2008.12.004

Mor A (2000) Peptide-based antibiotics: A potential answer to raging antimicrobial resistance. Drug Develop Res 50(3-4):440-447, doi:10.1002/1098-2299(200007/08) 50:3/4<440:Aid-Ddr27>3.0.Co;2-4

Mor A, Nicolas P (1994) The Nh2-terminal alpha-helical domain 1-18 of Dermaseptin is responsible for antimicrobial activity. J Biol Chem 269(3):1934-1939

Oren Z, Shai Y (1998) Mode of action of linear amphipathic a-helical antimicrobial peptides. Pept Sci 47(6):451-463, doi:10.1002/(SICI)1097-0282(1998)47:6<451: AID-BIP4>3.0.CO;2-F

Patel R (2005) Biofilms and antimicrobial resistance. Clin Orthop Relat Res 437:41-47

Projan SJ, Youngman PJ (2002) Antimicrobials: new solutions badly needed. Curr Opin Microbiol 5(5):463-465

Pronk S, Pall S, Schulz R, Larsson P, Bjelkmar P, Apostolov R, Shirts MR, Smith JC, Kasson PM, van der Spoel D, Hess B, Lindahl E (2013) GROMACS 4.5: a high-throughput and highly parallel open source molecular simulation toolkit. Bioinformatics 29:845-854, http://dx.doi.org/10.1093/bioinformatics/btt055

Schillaci D, Petruso S, Sciortino V (2005) 3,4,5,3 ',5'-Pentabromo-2-(2

'-hydroxybenzoyl)pyrrole: a potential lead compound as anti-Gram-positive and anti-biofilm agent. Int J Antimicrob Ag 25(4):338-340, doi:10.1016/j. ijantimicag.2004.11.014
Schillaci D, Arizza V, Parrinello N, Di Stefano V, Fanara S, Muccilli V, Cunsolo V Haagensen JJ, Molin S (2010) Antimicrobial and antistaphylococcal biofilm activity from the sea urchin Paracentrotus lividus. J Appl Microbiol 108(1):17-24, doi:JAM4394 [pii] 10.1111/j.1365-2672.2009.04394.x

Schillaci D, Vitale M, Cusimano MG, Arizza V (2012) Fragments of beta-thymosin from the sea urchin Paracentrotus lividus as potential antimicrobial peptides against staphylococcal biofilms. In: Goldstein AL, Garaci E (eds) Thymosins in Health and Disease li, vol 1270, Annals of the New York Academy of Sciences. Blackwell Science Publ, Oxford, pp 79-85

Schillaci D, Cusimano MG, Cunsolo V, Saletti R, Russo D, Vazzana M, Vitale M, Arizza $\vee$ (2013) Immune mediators of sea-cucumber Holothuria tubulosa (Echinodermata) as source of novel antimicrobial and anti-staphylococcal biofilm agents. AMB Express 3(1):35, doi:10.1186/2191-0855-3-35

Schumacher-Perdreau F, Heilmann C, Peters G, Götz F, Pulverer G (1994) Comparative analysis of a biofilm-forming Staphylococcus epidermidis strain and its adhesion-positive, accumulation-negative mutant M7. FEMS Microbiol Lett 117:71-78

Shai Y (1999) Mechanism of the binding, insertion and destabilization of phospholipid bilayer membranes by a-helical antimicrobial and cell nonselective membrane-lytic peptides. Biochim Biophys Acta Rev Biomembr 1462(1-2):55-70, http://dx.doi.org/10.1016/S0005-2736(99)00200-X

Shai $Y$ (2002) Mode of action of membrane active antimicrobial peptides. Biopolymers 66(4):236-248, doi:10.1002/Bip.10260

Sitaram N, Nagaraj R (2002) The therapeutic potential of host-defense antimicrobial peptides. Curr Drug Targets 3(3):259-267, doi:10.2174/1389450023347786

Skerlavaj B, Gennaro R, Bagella L, Merluzzi L, Risso A, Zanetti M (1996) Biological characterization of two novel cathelicidin-derived peptides and identification of structural requirements for their antimicrobial and cell lytic activities. J Biol Chem 271(45):28375-28381

Stabili L, Pagliara P (1994) Antibacterial protection in Marthasterias glacialis eggs: characterization of lysozyme-like activity. Comp Biochem Physiol B Biochem Mol Biol 109(4):709-713

Stark M, Liu LP, Deber CM (2002) Cationic hydrophobic peptides with antimicrobial activity. Antimicrob Agents 46(11):3585-3590

Storici P, Scocchi M, Tossi A, Gennaro R, Zanetti M (1994) Chemical synthesis and biological-activity of a novel antibacterial peptide deduced from a pig myeloid CDNA. FEBS Lett 337(3):303-307, doi:10.1016/0014-5793(94)80214-9

Tossi A, Scocchi M, Skerlavaj B, Gennaro R (1994) Identification and characterization of a primary antibacterial domain in Cap18, a lipopolysaccharide-binding protein from rabbit leukocytes. FEBS Lett 339(1-2):108-112, doi:10.1016/00145793(94)80395-1

Turner JD, Rouser G (1970) Precise quantitative determination of human blood lipids by thin-layer and triethylaminoethylcellulose column chromatography I Erythrocyte lipids. Anal Biochem 38(2):423-436

Verkleij AJ, Zwaal RFA, Roelofsen B, Comfurius P, Kastelijn D, van Deenen LLM (1973) The asymmetric distribution of phospholipids in the human red cell membrane. A combined study using phospholipases and freeze-etch electron microscopy. Biochim Biophys Acta Rev Biomembr 323(2):178-193, http://dx.doi.org/10.1016/ 0005-2736(73)90143-0

Wang Z, Wang G (2004) APD: the Antimicrobial Peptide Database. Nucleic Acids Res 32(Database issue):D590-D592, doi:10.1093/nar/gkh025

Wang G, Li X, Wang Z (2009) APD2: the updated antimicrobial peptide database and its application in peptide design. Nucleic Acids Res 37(Database issue): D933-D937, doi:10.1093/nar/gkn823

Wu G, Wu H, Fan X, Zhao R, Li X, Wang S, Ma Y, Shen Z, Xi T (2010) Selective toxicity of antimicrobial peptide S-thanatin on bacteria. Peptides 31:1669-1673, doi:10.1016/j.peptides.2010.06.009

Zasloff M (2002) Antimicrobial peptides of multicellular organisms. Nature 415(6870):389-395, doi:10.1038/415389a

doi:10.1186/s13568-014-0078-z

Cite this article as: Schillaci et al.: Paracentrin 1, a synthetic antimicrobial peptide from the sea-urchin Paracentrotus lividus, interferes with staphylococcal and Pseudomonas aeruginosa biofilm formation. AMB Express 2014 4:78. 